\title{
Teaching NeuroImage: Ganglion Cell Patterns Localize Anterior Visual Pathway Lesions
}

Gregg D. Miller, BA, Laurel N. Vuong, MD, and Thomas R. Hedges, III, MD

Neurology ${ }^{\circledR}$ 2021;97:e1637-1638. doi:10.1212/WNL.0000000000012200

Figure 1 Visual Fields, MRI, and Optical Coherence Tomography for 3 Cases of Optic Chiasm Compression

A

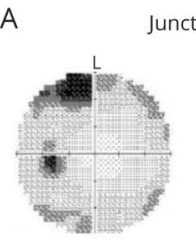

D
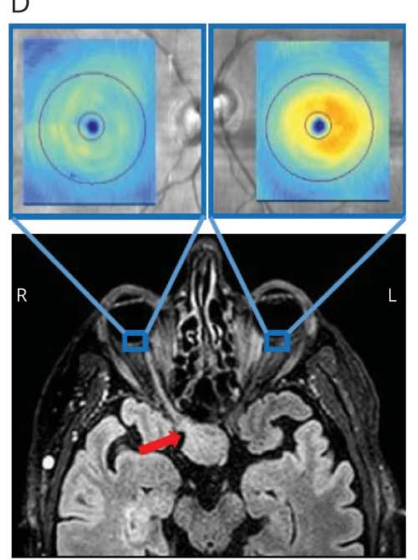

B
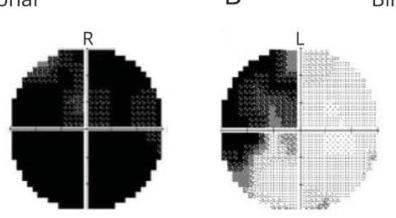

E
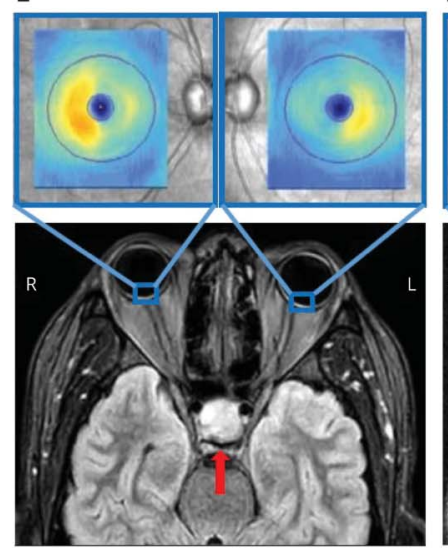

C Homonymous
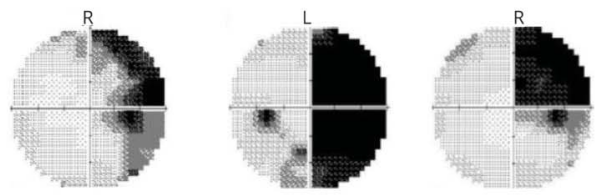

$\mathrm{F}$

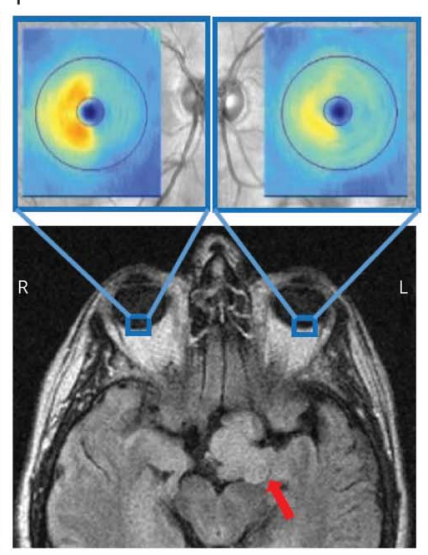

Anterior chiasmal compression by pituitary adenoma (red arrows) on T2-weighted axial MRI (D) corresponds to diffuse visual field loss (dark areas) of the ipsilateral eye with junctional scotoma of the contralateral eye superotemporally ( $A$ ) and diffuse ganglion cell thinning (blue areas) in the ipsilateral eye and inferonasal thinning in the contralateral eye on optical coherence tomography (D). Central compression corresponds to bitemporal hemianopia (B) and binasal ganglion cell thinning (E). Posterior compression corresponds to (an incongruous) contralateral homonymous hemianopia (C) and temporal ganglion cell thinning in the ipsilateral eye and nasal thinning in the contralateral eye $(F)$.

Measurement of retinal ganglion cell layer thickness by optical coherence tomography provides an objective and reliable evaluation of anterior visual pathway lesions to complement visual field testing in the management of optic chiasm compression from pituitary tumors. ${ }^{1,2}$ We demonstrated 3 differing patterns of ganglion cell layer thinning-junctional (figure 1, A and D), binasal (figure 1, B and E), and homonymous (figure 1, C and F) — and illustrated how these patterns correspond to the location of chiasmal compression by pituitary adenomas, anteriorly (figure $2 \mathrm{~A}$ ), centrally (figure $2 \mathrm{~B}$ ), or posteriorly (figure $2 \mathrm{C}$ ). Consideration of the pattern of ganglion cell layer thinning in conjunction with visual field testing is useful for predicting the location of anterior visual pathway lesions.

\author{
Correspondence \\ Dr. Hedges \\ thedges@ \\ tuftsmedicalcenter.org
}




$$
\text { A. Junctional }
$$

$\mathrm{R}$

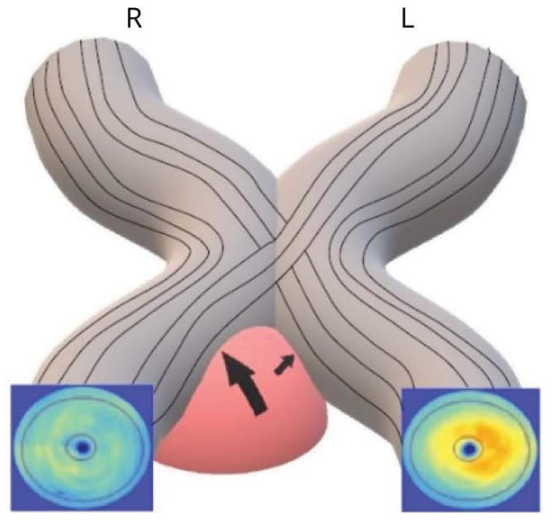

B. Binasal

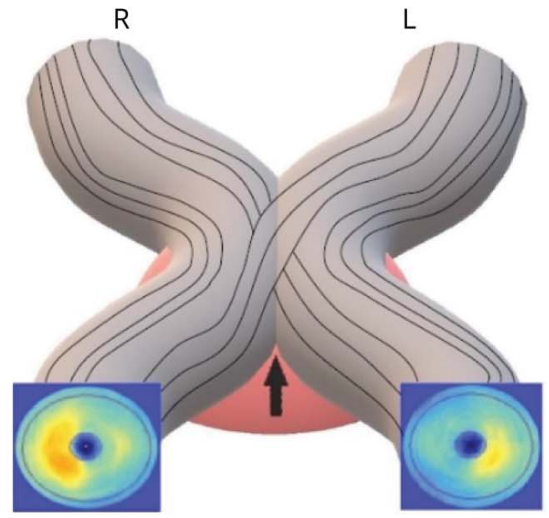

C. Homonymous

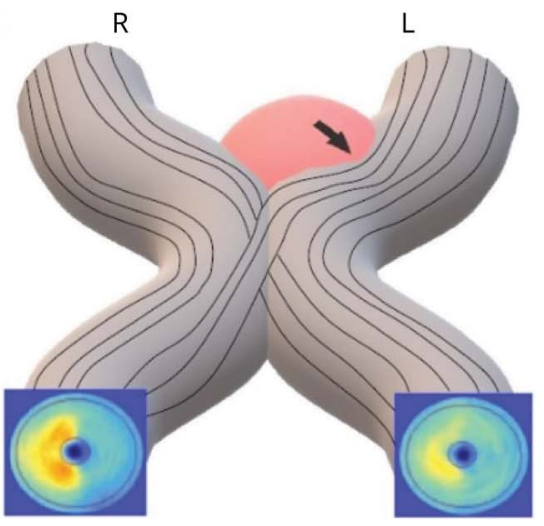

(A) Optic chiasm (gray) compression anteriorly by pituitary adenoma (pink) affecting the right optic nerve and inferomedial left optic nerve (black arrows). (B) Central optic chiasm compression by pituitary adenoma affecting the central chiasm. (C) Posterior optic chiasm compression by pituitary adenoma affecting the left optic tract.

\section{Study Funding}

The authors report no targeted funding.

\section{Disclosure}

The authors report no disclosures relevant to the manuscript. Go to Neurology.org/N for full disclosures.

\section{Appendix Authors}

\begin{tabular}{lll}
\hline Name & Location & Contribution \\
\hline Gregg D. & Tufts University School & Prepared the \\
Miller, BA & of Medicine, Boston & $\begin{array}{l}\text { manuscript, figures, and } \\
\text { PowerPoint }\end{array}$ \\
\hline
\end{tabular}

\begin{tabular}{lll} 
Appendix & (continued) & \\
\hline Name & Location & Contribution \\
\hline $\begin{array}{l}\text { Laurel N. } \\
\text { Vuong, MD }\end{array}$ & $\begin{array}{l}\text { New England Eye } \\
\text { Center, Boston }\end{array}$ & $\begin{array}{l}\text { Conceptualized and revised the } \\
\text { manuscript, treating physician }\end{array}$ \\
\hline $\begin{array}{l}\text { Thomas R. } \\
\text { Hedges III, MD }\end{array}$ & $\begin{array}{l}\text { New England Eye } \\
\text { Center, Boston }\end{array}$ & $\begin{array}{l}\text { Conceptualized and revised the } \\
\text { manuscript, treating physician }\end{array}$ \\
\hline
\end{tabular}

\section{References}

1. Tieger MG, Hedges TR, Ho J, et al. Ganglion cell complex loss in chiasmal compression by brain tumors. J Neuro-Ophthalmol. 2017;37(1):7-12.

2. Yum HR, Park SH, Park H-YL, Shin SY. Macular ganglion cell analysis determined by cirrus HD optical coherence tomography for early detecting chiasmal compression. PLoS One. 2016;11(4):e153064. 


\section{Neurology}

\section{Teaching NeuroImage: Ganglion Cell Patterns Localize Anterior Visual Pathway Lesions}

Gregg D. Miller, Laurel N. Vuong and Thomas R. Hedges III

Neurology 2021;97;e1637-e1638 Published Online before print May 13, 2021

DOI 10.1212/WNL.0000000000012200

\section{This information is current as of May 13, 2021}

\section{Updated Information \&} Services

References

Subspecialty Collections

Permissions \& Licensing

Reprints including high resolution figures, can be found at: http://n.neurology.org/content/97/16/e1637.full

This article cites 2 articles, 0 of which you can access for free at: http://n.neurology.org/content/97/16/e1637.full\#ref-list-1

This article, along with others on similar topics, appears in the following collection(s):

MRI

http://n.neurology.org/cgi/collection/mri

Optic nerve

http://n.neurology.org/cgi/collection/optic_nerve

Visual fields

http://n.neurology.org/cgi/collection/visual_fields

Visual loss

http://n.neurology.org/cgi/collection/visual_loss

Information about reproducing this article in parts (figures,tables) or in its entirety can be found online at:

http://www.neurology.org/about/about_the_journal\#permissions

Information about ordering reprints can be found online:

http://n.neurology.org/subscribers/advertise

Neurology ${ }^{\circledR}$ is the official journal of the American Academy of Neurology. Published continuously since 1951, it is now a weekly with 48 issues per year. Copyright () 2021 American Academy of Neurology. All rights reserved. Print ISSN: 0028-3878. Online ISSN: 1526-632X.

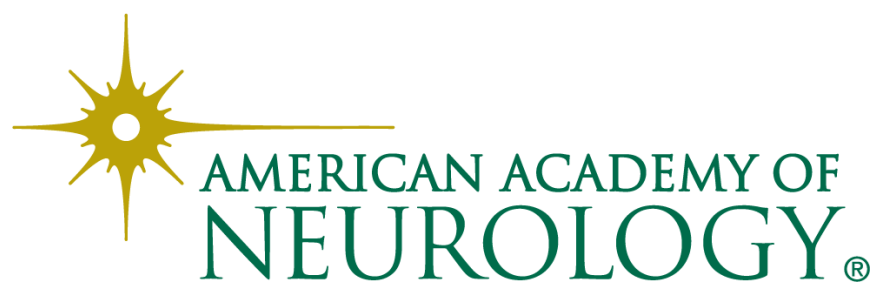

